\title{
Seasonal Variations in the Physico-Chemical Parameters of Malgujari Pond of Ghugus, District Chandrapur (Maharashtra)
}

\author{
L. S. Durge ${ }^{1 *}$, A.M. Chilke ${ }^{2}$, R. N. Chavhan ${ }^{3}$ \\ ${ }^{1}$ Department of Zoology, Dr. Ambedkar College of Arts, Commerce and Science, Chandrapur, India \\ ${ }^{2}$ Department of Zoology, Shri Shivaji College, Rajura, India \\ ${ }^{3}$ Department of Zoology,Mahatma Gandhi College, Armori,(M.S.), India
}

Available online at: www.isroset.org

Received: 05/Oct/2018, Accepted: 20/Oct/2018, Online: 31/Oct/2018

\begin{abstract}
A Malgujari pond,situated at the heart of Ghugus,an industrial town from district Chandrapur of Maharashtra has been selected for the study of seasonal variations in physic-chemical parameters of water. The period of the study is from December 2015 to November 2017. The following parameters viz-temperature, $\mathrm{pH}$, transparency, conductivity, $\mathrm{DO}$, free $\mathrm{CO}_{2}$, BOD,COD, total hardness, chlorides, phosphate, sulphate and nitrates has been taken for the analysis. The present study showed that the atmospheric temperature is higher than that of water. It is maximum during summer while the minimum in the winter season. Conductivity, $\mathrm{pH}$ and BOD are also observed maximum in summer while minimum in winter. DO as well as transparency is found maximum in the winter and minimum in monsoon. Free $\mathrm{CO}_{2}, \mathrm{BOD}, \mathrm{COD}$, hardness, chlorides, phosphates, sulphates and nitrates are maximum in summer and minimum in winter. Alkalinity is more in monsoon and found less in winter. Comparatively higher values of conductivity, total alkalinity, chlorides, phosphates and nitrates in Malgujari pond of Ghugus is an indication of its contaminated status.
\end{abstract}

Keyword: Water pollution, physico-chemical parameters, Malgujari pond.

\section{INTRODUCTION}

Life on the earth planet is never possible without water and is a most necessary component for living beings, and hence it is called Jiwanam in Sanskrit. It is one of the most vital elements for the human environment. It is useful for many purposes like drinking, irrigation, aquaculture and in many industrial processes. 71.9 percent of the earth surface has been covered by water (CIA, 2008),. Of this 96.5 percent is the sea water and is not directly used for any purpose. 1.7 percent is in the form of glaciers, and 1.7 percent is ground water. Only 0.1 percent of water is available for all of the processes of living beings. This particular topic has been chosen for the study to bring forward the pollution status of Malgujari pond, in terms of its physico-chemical parameters, as no such information about it is available. Shrivastava and Kanungo (2013), estimated that 70 percent of available water has been

polluted due to the discharge of industrial effluents,

domestic sewage, and agriculture drainages. Pesticides and fertilizers also add to water pollution. Though the water is the most important commodity of life, its quality is being degraded day by day. Several factors are responsible for the deterioration of water bodies. Some of them are the fast increasing human population, industrialization and excessive use of fertilizers. Some contagious diseases spread through water, so water quality must be good.
Malgujari pond is situated at the heart of the city is about 189 meters above mean sea level. Its geographical position is $19^{0} 56^{\prime}$ North and $79^{\circ} 08^{\prime}$ East. Water spread area of the pond is about in 20 acres. The depth of water in monsoon is about 15-18 feet and 4-5 feet during summer. The water from this pond is being used for agriculture and other domestic activities along with fishing. The present study deals with the seasonal variations of the physic-chemical parameters from December 2015 to November 2017.

\section{RELATED WORK}

Such type of work is carried out by N. V. Harney, A. A. Dhamani and R. J. Andrew on "Seasonal variations in the physico-chemical parameters of Pindwani pond of Central India." to observe the changes in the physico-chemical parameters with the changing climates. Their objective was to observe the variations in different parameters in different seasons.

\section{MATERIALS AND METHODS}

Collection of the water samples has been done at a depth of 1-1.5 meters from three marginal areas of the Malgujari pond. Sampling has been done in 2- liter capacity dried plastic cans with Reffner's sampler. Samples were collected in the morning hours between 8-10 am, every month for two years from December 2015 to November 2017. Recorded 
data was segregated in three seasons: Winter (Oct-Jan), summer (Feb-May) and Monsoon (Jun-Sept).

Atmospheric temperature and water temperature was measured with a mercury thermometer, $\mathrm{pH}$ with $\mathrm{pH}$ meter, transparency with the help of Sacchi disc, conductivity by using conductivity meter (Electronic India, Model EQ-660). Dissolved Oxygen measures with Winkler's method (1988), BOD by APHA method (2005), COD distillery assembly were used to estimate $\mathrm{COD}$. Free $\mathrm{CO}_{2}$, alkalinity, chlorides and hardness was done with titrimetric methods while phosphates, sulfates, and nitrates estimation are done with by spectrophotometer (Model UV-108).

\section{RESULTS AND DISCUSSION}

The physico-chemical parameters are the necessary basic characteristics to understand the tropical status of every ecosystem. Table 1 represents the average of the physicochemical parameters of two years, while Table 2 and 3 shows the seasonal variations of the pond under study. The present study of atmospheric temperature shows variations from $24.82^{\circ} \mathrm{C}$ to $45.82^{\circ} \mathrm{C}$. As the temperature rises, it accelerates the biochemical reaction reducing the solubility of gases. Water temperatures are fluctuating from $23.55^{\circ} \mathrm{C}$ to $33.89^{\circ} \mathrm{C}$. Atmospheric temperature has always observed more than the water temperature. All metabolic and physiological processes have been controlled by the water temperature, and thus it is a significant factor for calculating the solubility of Oxygen and Carbon Dioxide along with carbonate and bicarbonate equilibrium.

$\mathrm{pH}$ is an essential ecological factor and is the result of interactions of various substances in the solution form in water $\mathrm{pH}$ is a scale to know the intensity of acidity and alkalinity of any water body. By knowing $\mathrm{pH}$ of any water body, one can measure the hydrogen ion concentration of that water body. $\mathrm{pH}$ recorded in the study pond ranges from 6.87 to 7.77 . In the present work, higher $\mathrm{pH}$ values, recorded in summer, shows the correlation in the rise of temperature with the increased rate of photosynthesis resulting in the higher consumption of Carbon Dioxide.

Dissolved oxygen levels are considered as the most commonly used measurements and are very important for every fauna. In precipitation and dissolution of organic substances dissolved oxygen plays a key role. In the present investigation, dissolved oxygen values are seen running from $2.78 \mathrm{mg} / \mathrm{lit}$ to $3.50 \mathrm{mg} / \mathrm{lit}$. and are found maximum in the winter while minimum during summer. The higher values of dissolved oxygen in winter are because of low water temperature and high photosynthetic activities, while the lower in summer are due to high atmospheric temperature along with the high rate of oxidation of organic matters.
Free carbon dioxide dissolved in water is essentially the only source of carbon which is being assimilated and incorporated into the skeleton of living matter of all the aquatic autotrophs. Most of the carbon in fresh water system occurred as equilibrium products of carbon dioxide. Carbon dioxide is added to the aquatic ecosystem by other factors like rainwater, flowing ground water and respiration of aquatic flora and fauna. In the present investigation, the range of free carbon dioxide recorded is $2.15 \mathrm{mg} / \mathrm{lit}$. to 6.32 $\mathrm{mg} / \mathrm{lit}$. in Malgujari pond. In the present investigation, seasonal free carbon dioxide is maximum in monsoon and minimum in the winter season. The maximum values of free carbon dioxide in monsoon is due to the decomposition of organic matter and the respiration of aquatic flora and fauna. However, minimum free carbon dioxide during winter is probably due to a decreased photosynthetic activity of aquatic flora.

Transparency is a physical variable significant for primary production of the water body. It is mainly affected by the suspended particles and indirectly influenced by the physicochemical parameters. In the present investigation, Sacchi disc transparency was recorded at $19.95 \mathrm{~cm}$ to $31.34 \mathrm{~cm}$ in Malgujari pond. In the present study, maximum transparency was recorded during winter seasons and minimum during the monsoon.

The specific conductivity of water or a solution is its capacity to conduct electric current and depends on the nature and concentration of ionized salts. The conductivity of a sample is a numerical expression of its ability to carry an electric current which, in turn depends on the ionic strength. In the present investigation, the values of conductivity recorded are $156.50 \mu \mathrm{mhos} / \mathrm{cm}$ to 206.50 $\mu \mathrm{mhos} / \mathrm{cm}$ in Malgujari pond. In the present investigation, maximum seasonal conductivity was recorded during the summer season and minimum during the monsoon season.

Total Alkalinity is a measurement of the buffering capacity of the water. It is generally transmitted by the salts of carbonates, bicarbonates, phosphate, nitrates, borax, silicates, etc., together with the hydroxyl ions in a free state. In the present investigation, the total alkalinity ranged 9.50 $\mathrm{mg} /$ lit. to $21.00 \mathrm{mg} / \mathrm{lit}$. in Malgujari pond. In this present research work, seasonal variations in total alkalinity were minimum in summer and maximum in winter in Malgujari pond. In the present research work, maximum values of alkalinity during winter may be due to household detergent products added in the pond only in the winter season, due to flooding of city channels after their saturations in summer, while the minimum values during summer may be due to the moderate use of bicarbonates by the pond biota directly for their load. Thus the concentration of bicarbonates leads to the depletion in water resulting in low values of total alkalinity. 
Total hardness of the water is a sum of the concentrations of alkaline earth metals cations. Hardness is generally governed by calcium and magnesium salts which largely combines with bicarbonates and carbonates giving temporary hardness and with sulfates, chlorides and others anions of a minerals acids causing permanent hardness. In the present investigation, the total hardness was recorded in the range of $71.19 \mathrm{mg} / \mathrm{lit}$. to $150.40 \mathrm{mg} / \mathrm{lit}$. in Malgujari pond. The maximum values of total hardness observed during summer and minimum in the winter season. The higher values in summer may be due to the higher temperatures which increases the concentrations of salts by excessive evaporation.

Calcium is an important constituent in natural water. It has been known that calcium content plays an important role in the biological productivity of the lakes and ponds. Magnesium is one of the main constituents in natural waters and is a vital component of chlorophyll. In the present investigations, in Malgujari pond, the calcium hardness recorded is in the range of $36.50 \mathrm{mg} / \mathrm{lit}$. to $95.18 \mathrm{mg} / \mathrm{lit}$. While magnesium observed ranging from $15.75 \mathrm{mg} / \mathrm{lit}$ to $51.25 \mathrm{mg} / \mathrm{lit}$. In the present investigation, calcium and magnesium hardness was minimum during winter and maximum during the summer season. An increase in calcium and magnesium concentrations during premonsoon may be the effect of bacterial decompositions. In the present investigation, the maximum values of calcium and magnesium hardness were due to low water levels and bacterial decompositions of the organic matter in the lake.

Chlorides as anions were found in all natural waters in widely differing concentrations. The origin of chlorides in surface waters is from leaching of sedimentary rocks, domestic and industrials wastes discharged by municipal influents, and weathering of rocks, etc. In the present investigation, the values of chloride recorded are 11.42 $\mathrm{mg} / \mathrm{lit}$. to $26.24 \mathrm{mg} / \mathrm{lit}$. in Malgujari pond. In the present investigation, minimum chloride was recorded during monsoon season and maximum during the summer season in Malgujari pond at Ghugus.

Biochemical Oxygen Demand is an indicator parameter to know the presence of biodegradable matter in the waste and expresses the degree of contamination. Biochemical oxygen demand is being used as a major indicator of the amounts of organic materials in an aquatic solution which supports the growth of microorganisms. In the present investigation, the biochemical oxygen demand values recorded are $5.50 \mathrm{mg} / \mathrm{lit}$. to $13.50 \mathrm{mg} / \mathrm{lit}$. in Malgujari pond. In the present investigation, the maximum biochemical

oxygen demand value was recorded during monsoon and minimum during the winter season. Patel (1999) reported higher biochemical oxygen demand values in summer and stated that it may be due to higher microbial activities. In the present investigations, the maximum biochemical oxygen demand in summer is probably due to high microbial activities during summer.

The Chemical Oxygen Demand (COD) test is commonly used indirectly to measure the number of organic compounds in water. An amount of organic pollutants found in surface water is determined by so many applications of COD determination which makes COD as a useful domain of water quality. In the present investigation, the chemical oxygen demand values recorded are $9 \mathrm{mg} / \mathrm{lit}$. to $20.50 \mathrm{mg} / \mathrm{lit}$. in Malgujari pond. Thirumala et al., (2006) recorded the chemical oxygen demand values between $27.42 \pm 22.304$ $\mathrm{mg} / \mathrm{lit}$. In the present investigation, maximum chemical oxygen demand was recorded during the summer and minimum during the winter season. In these studies, higher values of COD during summer maybe due to higher decomposition activities and low levels of water. However, minimum chemical oxygen demand in winter is due to low temperature, low decomposition activities and dilution effect.

Phosphorus is found naturally in rocks and other mineral deposits. Phosphorus moves in a cyclic manner through rocks, water, soil and sediments of organisms. Overtime rain and causes rocks to release phosphorus as phosphate ions which are soluble in water. In the present investigation, phosphate is recorded between $0.12 \mathrm{mg} / \mathrm{lit}$. to $0.19 \mathrm{mg} / \mathrm{lit}$. in Malgujari pond. In this research work, the higher values of phosphorus are observed in summer while lower values in winter. The higher values of phosphate during summer seasons maybe due to rapid evaporation and mineralization of decomposed materials in pond water.

Sulphur is one of the widely occurring elements and constitutes nearly $0.1 \%$ in the earth crust. It occurs as hydrogen sulphide in spring waters, coal, gas, sewage gas etc. In natural water, sulphide is the second most common anion, being from most sedimentary rocks. In the present investigation, the values of sulphate recorded are $0.90 \mathrm{mg} / \mathrm{lit}$. to $1.65 \mathrm{mg} / \mathrm{lit}$. in Malgujari pond. In the present investigation, maximum sulphate level was recorded during summer and minimum during the winter season. In the present study, higher concentration of sulphur recorded in summer is probably due to the activity of biodegradation whereas dilution and utilization of sulphate by the aquatic plants gradually brought down the sulphate concentration in monsoon followed by winter.

Nitrate content is an excellent parameter to judge organic pollution and it represents the highest oxidized form of nitrogen. The nitrates are an important source of nitrogen for phytoplankton. In the present investigation, the values of nitrate range between $0.12 \mathrm{mg} / \mathrm{lit}$. to $0.30 \mathrm{mg} / \mathrm{lit}$. in Malgujari pond. In the present investigation, maximum nitrate was recorded during the monsoon and minimum 
during the winter season. The seasonal physico-chemical parameters of Malgujari pond exhibit cyclical variations. The slight high value of conductivity, total alkalinity, chloride, Phosphate and Nitrate in Malgujari pond indicate towards its slight polluted nature and it exhibits a slightly polluted status.

\section{CONCLUSION AND FUTURE SCOPE}

The present study was conducted to find out the seasonal variations in the water quality parameters of a water body situated at the heart of an industrial town-Ghugus of district Chandrapur (M.S.) India. The period of the study was from December 2015 to November 2017. DO, transparency and alkalinity was observed maximum in the winter seasons, while the values of DO and alkalinity are seen less in the summers.

Atmospheric temperature, water temperature, conductivity, $\mathrm{pH}$, hardness, COD, chlorides, phosphate and sulphate values are more in the summers but these values are less in the winters. Higher values of $\mathrm{CO}_{2}, \mathrm{BOD}$ and nitrates observed in the monsoon while the values of these parameters are less in the winters.

Thus by studying the seasonal variations in the physicochemical parameters of this Malgujari pond it become clear that the pond is slightly polluted in nature and can't be used for the drinking purpose, though the water from this pond may be used for irrigation and other household purposes.

\section{REFERENCES}

[1]. ADE, P.P. \& VANKHEDE, G.N. (2001) Limnological studies of Amravati University reservoir with reference to trophic status \& conservation. Ph.D. Thesis, Amravati university, Amravati.

[2]. ADONI, A.D. (1985) Studies on microbiology of Sagar Lake, Ph.D. Thesis, Sagar University Sagar, Madhya Pradesh. pp. 243

[3]. ADONI, A.D. (1985) Work book on Limnology, Dept. of Environment, Govt. of India, Bandana printing service, New Delhi.

[4]. APHA (2005) Standard methods for examination of water and wastewater.21st Edn.washington D.C.

[5]. BARTHOLOW, J.M., R.B. HANNA, L. SAITO, D. LIEBERMAN, \& M. HORN. (2001). Simulated limnological effects of the Shasta Lake temperature control device. Environmental Management 27(4):609-627.

[6]. BHATT, L. R., LACOUL, P., LEKHAK, H. D. \& JHA, P. K. (1999) Physico-chemical characteristics of Taudaha lake,Kathmandu. Poll. Res. 18(4): 353-358.

[7]. DEVI, M.J.(1985) Ecological studies of the Limnological plankton of three water bodies of Hyderabad. Ph.D. thesis Osmania University.

[8]. GANPATI, S.V. (1960) Ecology of tropical waters. Proc. Symp. Alga. 200-218.

[9]. GURAISWAMY, K. (1988) Limnological studies on certain freshwater bodies of Salem. M.Phil. Desser., Madras Univ. India.

[10]. (HAZELWOOD, D.H. \& R.A. PARKER 1961) Population dynamics of some freshwater zooplankton. J.Ecology 42:266-274

[11]. HUTCHINSON, G.E. (1957) A treatise on limnology Vol. I \& II Geography, Physics \& Chemistry. John Willey Inc. New York 1015.
[12]. JAIN, C.K. \& SEETHAPATI, P.V. (1996) Limnological studies of kay Amkula Lake. Indian J. Environ. Protection. 16: 61-568

[13]. JAKHER, G.R. (2002) Variation in different bacterial count in a fresh water pond of Jodhpur, Rajasthan, India. Oikoassay. 15 (1\& 2): 1-5.

[14]. JINGRAN, V. G. (1982) Fish and fisheries of India, Hindustan Pub. Corp. New Delhi, India. 268-269 pp.

[15]. KEDAR, G.T., PATIL, G.P. \& YEOLE, S.M. (2007) Rotifer biodiversity of Yedshi Lake, Maharashtra. J. Aqua. Biol. 22(1): 812.

[16]. KEDAR, G.T. \& PATIL, G.P. (2011) Study on seasonal fluctuation in physico-chemical parameters of Rishi Lake, Karanja (Lad), Dist. Washim, Maharashtra. (NCEBB-2011) pp.120-122.

[17]. KHAN, M.A.G. \& CHAUDHARY, S. H. (1994) Physical and chemical limnology of lake Kapta, Bangladesh. Trop. Ecol.35 (1): 35-51.

[18]. MESHRAM, C.B. (1996) Limnological studies of Wadali Lake, Amravati. Ph.D. Thesis, Amravati University Amravati.

[19]. MUNAWAR, M.C. (1970) Limnological studies on freshwater ponds of Hydrabad-1. The Biotope. Hydrobiologia. 25 (1): 127162.

[20]. NARAYANA, J., PURUSHOTHAMA, R., KIRAN, B.R., RAVINDRAKUMAR, K.P. \& PUTTAH, E.T. (2005) Investigation of drinking water quality of Basavanahole Tank with reference to physical chemical characteristics. Fundamental of limnology, 201-206.

[21]. PEJAWAR, MADHURI, VAISHALI SOMANI AND GOLDIN QUADROS (2004) Physico chemical parameters of two quarry lakes, near thane city, Maharashtra. J. Aqua. Biol. 19(1): 107-110.

[22]. RAVI KUMAR, M., MANIJAPPA, S., KIRAN, B.R. \& PUTTAIAH, E.T. (2005) Hydrochemistry of Ayyanakere Tank in Harpanhalli Town, Davanagere, Karnataka. J. Aqua. Biol. 20(2): 117-120.

[23]. RAI, H. (1974) Limnological observation on the different rivers and lakes in the Ivory coast, Hydrobiologia. 44(2 \& 3): 301-317.

[24]. SINGH, S.R. \& SWARUP, K. (1979) Limnological studies of Surha Lake (Ballia) II. The periodicity of plankton. Indian Bot. Soc. 58: 319-329.

[25]. SREENIVASAN, A. (1966) Limnology of tropical impoundments. Hydroriological and fish production in Stanley reservoir, Mettur Dam. Hydrobiol. 51(2): 295-306.

[26]. TRIVEDI, R.K. \& GOEL, P.K. (1984) Chemical and Biological methods for water pollution studies. Karad Environmental publication, pp. 1-251.

[27]. WELCH, M.N. (1952) Limnology, McGraw Hill Book Co. Inc. NY.pp.538.

[28]. SALVE, B.S. \& HIWARE, C.J. (2006) Studies on water quality of Wanaprakalpa reservoir, Nagapur near Parali Vaijnath, Dist. Beed, Marathwada region. J. Aqua. Biol. 21(2): 113-117.

[29]. WETZEL, R.G. (1975, 2001) Limnology, W.B. Saunders Co. Philadelphia, pp.743.

\section{Author's Profile:}

Mr. L. S. Durge completed his B.Sc. from St. Francis De' Sales College, Seminary Hills, Nagpur in 1984, and M.Sc. in 1986 with the specialization Fresh Water Zoology from institute of science, Nagpur, both the degrees from Nagpur University, Nagpur (M.S.) India. He worked as a Lecturer in Zoology at R.D. Science College, Aheri, Nabira Mahavidyalaya, 
Katol and Javahar Lal Nehru Science College, Saoner. At present he is working as an Associate Prof. with a teaching experience of 25 years to U.G. and 15 years to P.G. classes at Dr. Ambedkar College of Arts, Commerce and Science, Chandrapur (M.S.), India. $\mathrm{He}$ is also engaged in social activities like participation in blood donation camps, awaring the people about family planning, etc. Currently he is doing Ph.D. from Gondwana University, Gadchiroli (M.S.), India. His area of research is Physico-Chemical Characteristics of a Fresh Water Pond of Ghugus, District Chandrapur, Maharashtra (India).

Mr. A. M. Chilke did his B. Sc. from Sarvodaya Mahavidyala Sindevahi, district Chandrapur and M. Sc. From Nagpur University, Nagpur in 1991 with a specialization in Fish and Fisheries. He completed his $\mathrm{Ph}$. D. from the same university in 2006 under the able guidance of Dr. V. V. Baile. At present he is working as an Associate Professor and Head in the department of Zoology, in Shri Shivaji College, Rajura, district Chandrapur (Maharashtra). $\mathrm{He}$ is being registered as a $\mathrm{Ph}$. D. Supervisor at Gondwana University, Gadchiroli. His publication is in 20 National and 18 Internatinational Journals. Under his supervision 2 students are awarded by Ph. D. Degree and 05 students are doing Ph. D. Dr. Chilke participated in 41 National and International Conferences, Seminars and Workshops with the paper presentations.
Mr. R. N. Chavhan completed his B.Sc. in 1993 from Amaravati University and M.Sc. from the same University in 1996.he is awarded with Ph. D. Degree by R.T.M. Nagpur University in 2012. His topic of research was, "Limnological studies in respect to physico-chemical and biological characteristics of Ramsagar Lake,

Armori,dist- Gadchiroli (M.S.) India". He worked on a U.G.C. sponsored minor research project entitled "Hydrological studies of some lentic ecosystems from Gadchiroli district of Maharastra state, India with respect to vertebrate fauna and Macro invertebrate species diversity" Sanctioned letter reference no.- F.No.47-1742/10 (WRO) Date:-25/5/2011. Total Sanctioned amount Rs.80000/- . At present he is working as an Assistant Prof. at Mahatma Gandhi Arts, Science and late N. P. Commerce College, Armori, DistrictGadchiroli 441208 (M.S.) Indiasince2000. He is registered as Ph. D. Supervisor at Gondwana University, Gadchiroli in 2013. He published 07 National and 10 International papers in different journals till now. He participated 35 Conferences, seminars and Work-shops with 15 abstracts, 3 posters and 17 oral presentations.

\section{Observations:}

Observations have been recorded in the following tables.

Table 1: Two years average of selected physico-chemical parameters of Malgujari pond for the period 2015-2017

\begin{tabular}{|c|c|c|c|c|c|c|c|c|c|c|c|c|c|}
\hline Sr.No. & Parameters & Dec. & Jan. & Feb. & Mar. & Apr. & May. & Jun. & Jul. & Aug. & Sept. & Oct. & Nov. \\
\hline 1 & Atmospheric Temperature & 25.18 & 26.43 & 24.82 & 26.68 & 39.73 & 45.82 & 44.69 & 36.17 & 32.68 & 33.79 & 34.52 & 33.55 \\
\hline 2 & Water Temperature & 24.27 & 23.55 & 23.67 & 25.31 & 26.64 & 31.71 & 33.79 & 33.89 & 33.09 & 31.41 & 28.57 & 27.39 \\
\hline 4 & D.O. & 3.28 & 3.30 & 3.47 & 3.49 & 2.81 & 2.84 & 2.78 & 2.79 & 3.16 & 2.99 & 2.85 & 2.89 \\
\hline 5 & $\mathrm{CO} 2$ & 2.69 & 2.55 & 2.25 & 2.15 & 3.26 & 3.34 & 5.08 & 6.32 & 6.22 & 5.00 & 5.11 & 4.99 \\
\hline 8 & Total Alkalinity - M.O. & 17.50 & 16.00 & 14.50 & 13.50 & 11.00 & 10.50 & 9.50 & 9.50 & 10.00 & 14.00 & 21.00 & 19.50 \\
\hline 9 & Hardness - Total & 79.20 & 81.45 & 71.19 & 87.15 & 110.10 & 145.70 & 150.40 & 140.30 & 137.10 & 132.15 & 126.15 & 110.10 \\
\hline 10 & Hardness - Cal. & 38.60 & 36.50 & 48.80 & 60.40 & 80.84 & 92.15 & 95.18 & 91.95 & 87.20 & 85.70 & 82.60 & 70.10 \\
\hline 11 & Hardness - Mag. & 24.55 & 21.80 & 20.10 & 15.75 & 32.15 & 48.55 & 50.30 & 51.25 & 42.95 & 43.45 & 41.90 & 39.22 \\
\hline 12 & Chlorides & 18.80 & 16.75 & 20.80 & 22.50 & 23.20 & 24.12 & 26.24 & 22.46 & 19.99 & 15.35 & 11.42 & 13.25 \\
\hline 16 & Sulphate & 0.90 & 1.00 & 1.30 & 1.45 & 1.60 & 1.65 & 1.45 & 1.20 & 1.60 & 1.20 & 1.15 & 1.20 \\
\hline 17 & Nitrate & 0.18 & 0.17 & 0.18 & 0.12 & 0.21 & 0.16 & 0.20 & 0.23 & 0.25 & 0.26 & 0.30 & 0.29 \\
\hline
\end{tabular}


Table 2: Seasonal variations in physico-chemical parameters during 2015-2016 in Malgujari pond.

\begin{tabular}{|c|c|c|c|c|}
\hline \multirow{2}{*}{ Sr.No. } & \multirow{2}{*}{ Parameters } & Winter & Summer & Monsoon \\
\hline & & Mean & Mean & Mean \\
\hline 2 & Water Temperature & $24.450 \pm 2.401$ & $31.507 \pm 4.404$ & $30.115 \pm 1.627$ \\
\hline 4 & D.O. & $3.385 \pm 0.243$ & $2.805 \pm 0.262$ & $2.972 \pm 0.096$ \\
\hline 5 & $\mathrm{CO} 2$ & $2.410 \pm 0.817$ & $4.500 \pm 1.809$ & $5.330 \pm 0.500$ \\
\hline 7 & Conductivity & $176.875 \pm 14.841$ & $186.000 \pm 17.035$ & $173.750 \pm 25.645$ \\
\hline 8 & Total Alkalinity - M.O. & $15.375 \pm 2.062$ & $10.125 \pm 0.803$ & $11.625 \pm 4.969$ \\
\hline 9 & Hardness - Total & $79.747 \pm 8.947$ & $136.625 \pm 19.990$ & $126.375 \pm 13.073$ \\
\hline 10 & Hardness - Cal. & $46.075 \pm 10.299$ & $90.030 \pm 8.655$ & $81.400 \pm 4.028$ \\
\hline 11 & Hardness - Mag. & $20.550 \pm 8.718$ & $45.562 \pm 11.347$ & $41.880 \pm 9.129$ \\
\hline 15 & Phosphate & $0.137 \pm 0.013$ & $0.180 \pm 0.007$ & $0.165 \pm 0.005$ \\
\hline 16 & Sulphate & $1.162 \pm 0.196$ & $1.475 \pm 0.499$ & $1.287 \pm 0.112$ \\
\hline 17 & Nitrate & $0.162 \pm 0.043$ & $0.200 \pm 0.023$ & $0.275 \pm 0.008$ \\
\hline
\end{tabular}

Table 3: Seasonal variations in physico-chemical parameters during 2016-2017 in Malgujari pond.

\begin{tabular}{|c|c|c|c|c|}
\hline \multirow[t]{2}{*}{ Sr.No. } & \multirow[t]{2}{*}{ Parameters } & Winter & Summer & Monsoon \\
\hline & & Mean & Mean & Mean \\
\hline 1 & Atmospheric Temperature & $25.645 \pm 2.932$ & $41.552 \pm 4.178$ & $33.595 \pm 3.984$ \\
\hline 2 & Water Temperature & $24.395 \pm 2.809$ & $31.635 \pm 5.221$ & $29.508 \pm 2.490$ \\
\hline 3 & $\mathrm{pH}$ & $7.258 \pm 0.440$ & $7.513 \pm 0.413$ & $7.165 \pm 0.061$ \\
\hline 4 & D.O. & $3.265 \pm 0.029$ & $2.955 \pm 0.038$ & $2.995 \pm 0.017$ \\
\hline 5 & $\mathrm{CO} 2$ & $2.575 \pm 0.411$ & $4.685 \pm 1.846$ & $5.225 \pm 1.021$ \\
\hline 6 & Transparency & $30.700 \pm 1.082$ & $27.550 \pm 1.936$ & $21.250 \pm 1.936$ \\
\hline 7 & Conductivity & $178.750 \pm 17.412$ & $189.275 \pm 12.949$ & $174.255 \pm 19.575$ \\
\hline 8 & Total Alkalinity - M.O. & $15.450 \pm 2.915$ & $10.115 \pm 0.606$ & $11.750 \pm 6.205$ \\
\hline 9 & Hardness - Total & $80.215 \pm 13.704$ & $139.405 \pm 16.438$ & $128.720 \pm 11.842$ \\
\hline 10 & Hardness - Cal. & $47.128 \pm 16.010$ & $98.330 \pm 2.823$ & $81.245 \pm 12.049$ \\
\hline 11 & Hardness - Mag. & $20.653 \pm 13.346$ & $44.478 \pm 14.966$ & $41.665 \pm 0.444$ \\
\hline 12 & Chloride & $19.560 \pm 1.912$ & $25.265 \pm 0.729$ & $12.758 \pm 3.682$ \\
\hline 13 & B.O.D. & $6.325 \pm 0.500$ & $10.750 \pm 2.236$ & $11.255 \pm 3.112$ \\
\hline 14 & C.O.D & $10.250 \pm 1.920$ & $20.750 \pm 1.090$ & $17.225 \pm 2.487$ \\
\hline 15 & Phosphate & $0.143 \pm 0.019$ & $0.184 \pm 0.008$ & $0.173 \pm 0.007$ \\
\hline 16 & Sulphate & $1.420 \pm 0.333$ & $1.690 \pm 0.279$ & $1.305 \pm 0.351$ \\
\hline 17 & Nitrate & $0.210 \pm 0.065$ & $0.275 \pm 0.0780$ & $0.368 \pm 0.038$ \\
\hline
\end{tabular}

Table No. 1: Two years average of Physico-chemical parameter in Malgujari Pond during year 2015-17

Table No. 2: Seasonal variation of Physico-chemical parameter in Malgujari Pond During 2015-16

Table No. 3: Seasonal variation of Physico-chemical parameter in Malgujari Pond During 2016-17 